\title{
PENGARUH KOMPENSASI DAN DISIPLIN KERJA TERHADAP KINERJA PEGAWAI HONORER DINAS BIMATARUNG PROVINSI SULAWESI TENGAH
}

\author{
NURHANISPA \\ IDRIS AZIS \\ WIRI WIRASTUTI \\ Program Studi S1 Manajemen, Fakultas Ekonomi, Universitas Tadulako \\ Email: Nurhanisfah@gmail.com; Azis_idris62@yahoo.com;
}

\begin{abstract}
The purrpose of this study was to determne and analyze the effect of compensation and work discipline simultaneusly and partialy on the performance of honorary employes of the Office of Highways and Spatial Planning of Prov. Central Sulawesi. The independent variabels of this studi are compensaton and work discipline. While the dependent variable is employee performance. The research method used is associative method with a sample of 62 people. form of sampling using census techniques. Data analysis method used in this study is a multiple linear regression analysis method. The results show that: 1). Compensation and work discipline simultaneously have a significant effect on the performance of honorary employees; 2). Partial compensation has a significant efect on the performance of honorary employees; 3). Work discipline partially has a significant efect on the performance of honorary employes of the Office of Highways and Prov. Central Sulawesi.

Keywords: Compensation, Work Discipline, Performance Employees
\end{abstract}

\begin{abstract}
ABSTRAK
Tujuan penelitian ini adalah untuk mengetahu dan menganaliis pengaruh kompensasi dan disiplinkerja secara simultan dan parsial kepada kinerja pegawai honorer Dinas Bina Marga dan Penataan Ruang Prov. Sulawesi Tengah. Variabel independen dari penelitian ini yaitu kompensasi dan disiplin kerja. Sedangkn variabel dependen yaitu kinerja pegawai. Metode penelitian yang di gunakan adalah metode asosiatif dengan jumlah sampel 62 orang. Bentuk pengambilan sampel mengunakan teknik sensus. Metode analisis data yang digunakan dalam penelitian ini adalah metode analisis regresi linear berganda. Hasil penelitian menunjukan bahwa: 1). Kompensasi dan disiplin kerja secara simultan pengaruhnya signifikan terhadap kinerja pegawai honorer; 2). Kompensasi secara parsial pengaruhnya signifikan terhadap kinerja pegawai honorer; 3). Disiplin kerja secara parsial pengaruhnya signifikan terhadap kinerja pegawai honorer Dinas Bina Marga dan Penataan Ruang Prov. Sulawesi Tengah.
\end{abstract}

Kata Kunci: Kompensasi, Disiplin Kerja dan Kinerja Pegawai

\section{PENDAHULUAN}

Sumber daya manusia mempunyai peranan utama dalam meningkatkan kinerja pegawai pada sebuah instansi khususnya instansi milik pemerintah. Pihak instansi harus lebih memberdayakan pegawainya agar pegawai tersebut mampu menghasilkan suatu kinerja yang berkualitas dan unggul. bukan saja pada pegawai tetap bahkan juga berlaku sama pegawai yang masih honorer. Keberhasilan seorang pegawai dalam melakukan pekerjaanya dapat dinilai atau dilihat dari hasil kinerjanya. Satu dari banyak hal yang mempengaruhi kinerja pegawai yaitu penerapan kompensasi.

Kompensasi adalah balas jasa yang diberikan instansi dalam bentuk uang, barang langsung atau tidak langsung yang diperoleh karyawan sebagai imbalan atas pekerjaanya yang diberikan kepada organisasi 
tempat manusia itu bekerja. Semakin besar kompensasi yang diterima maka akan semakin tinggi pula semangat yang dirasakan pegawai dalam bekerja (Hasibuan 2009:118). Pemberian kompensasi kepada pegawai honorer pada dinas ini dinilai belum maksimal meningkatkan kinerja pegawai dalam bekerja. hal ini juga dilihat dengan adanya pegawai yang masih bersifat pasif terhadap tugas yang diberikan serta dalam penyelesaian tugasnya tak sama pada waktu yang telah ditentukan.

Selain kompensasi beberapa aspek juga perlu untuk dilihat seorang pegawai untuk bekerja adalah disiplin kerja. Disiplin kerja merupakan kemauan seseorang yang muncul oleh pemikirannya sendiri untuk mentaati aturan yang ada dalam instansi tempat manusia itu bekerja, disiplin kerja bertujuan untuk meningkatkan kesadaran pegawai bahwa dalam bekerja pegawai harus mematuhi setiap tata tertib dan aturan yang berlaku dalam suatu organisasi, tidak hanya itu pegawai diharapkan mampu untuk meningkatkan kualitas kerjannya (Sinambela, 2012:237). Disiplin kerja pegawai honorer masih belum baik, hal ini terlihat dari adanya pegawai yang masuk kerja tidak tepat waktu atau datang terlambat, adanya pegawai yang keluar pada saat jam kerja, adanya pegawai yang berpakaian tidak rapi serta masih ditemukannya pegawai yang tidak mengikuti apel pagi maupun apel pulang. Pada tahun 2016, pihak instansi telah memecat pegawai honorer sebanyak 3 orang dengan alasan kurangnya kedisiplinan pegawai tersebut

kinerja adalah perbandingan hasil kerja seorang pegawai untuk menjalankan tugas mengikuti standar kerja yang sudah disepakati dari pihak instansi atau perusahaan tempat pegawai itu bekerja, Wilson Bangun (2012: 231). Permasalahan pada Dinas Bina Marga dan Penataan Ruang Prov. Sulawesi Tengah menunjukan bahwa kinerja pegawai honorer pada instansi tersebut belum dapat memaksimalkan tujuan instansi, hal ini terjadi karena menurunnya kinerja pegawai mengakibatkan terlambatnya proses pembangunan dan perbaikan jalan dan jembatan, karena bahan-bahan yang dibutuhkan tidak datang tepat waktu, sehingga hal ini akan berdampak pada aktivitas sehari-hari masyarakat.

Adapun tujuan yang akan diperoleh pada penelitian ini yaitu:

1. Untuk mengetahui dan menganalisis pengaruh kompensasi dan disiplin kerja pada kinerja pegawai honorer pada Dinas Bina Marga dan Pentaan Ruang Prov. Sulawesi Tengah

2. Untuk mengetahui dan menganalisis kompensasi berpengaruh secara parsial pada kinerja pegawai honorer Dinas Bina Marga dan Penataan Ruang Prov. Sulawesi Tengah

3. Untuk mengetahui dan menganalisis disiplin kerja berpengaruh secara parsial pada kinerja pegawai honorer pada Dinas Bina Marga dan Penataan Ruang Prov. Sulawesi Tengah

\section{KAJIAN LITERATURE DAN PENGEMBANGAN HIPOTESIS}

Kompensasi merupaka balas jasa yang diberikan instansi dalam bentuk uang, barang langsung atau tidak langsung yang diperoleh karyawan sebagai imbalan atas pekerjaanya yang diberikan kepada organisasi tempat manusia itu bekerja (Hasibuan: 2009:118). Kompensasi dalam hal ini akan dimasukan pada 2 golongan besar, yaitu: kompensasi langsung (direct compensation) dan kompensasi tidak langsung (indirect compensation). Adapun komponen-komponen kompensasi meliputi:

1. Kompensasi langsung: Gaji, merupakan imbalan yang akan dibayarkan secara periodik pada pegawai dan memiliki jaminan yang pasti. Upah, merupakan imbalan yang akan terbayarkan pada pekerja harian tetapi berpedoman dengan perjanjian yang disetujui. Tetapi dalam penelitian ini upah tidak digunakan karena dinas ini tidak menerapkan sistem upah. Serta Insentif, merupakan bonus imbalan yang akan diberikan pada pegawai tertentu yang prestasinya melebihi kriteria tertentu.

2. Kompensasi tidak langsung: adalah imbalan berupa tambahan yang diberikan didasarkan pada kebijakan tertentu pada semua pegawai sebagai upaya meningkatkan kesejahteraan mereka. Yaitu fasilitas, merupakan semua bentuk barang yang diberikan pada pegawainya sebagai bentuk peningkatan semangat kerja pegawai dan tunjangan yang merupakan bentuk pembayaran tidak langsung yang diberikan pada pegawai untuk memotivasi mereka dalam bekerja. 
Disiplin kerja merupakan kemauan seseorang yang muncul oleh pemikirannya sendiri untuk mentaati aturan yang ada dalam instansi, Sinambela (2012:237). Menurut Soetrisno (2014:69), yang menunjukan mengenai disiplin kerja yang terbagi atas 3 yaitu:

1. Disiplin Waktu, artinya bagaimana seorang pegawai memanajemen waktunya sesuai dengan ketetapan dalam hal ini adalah waktu mulai kerja, waktu istirahatnya, waktu selesai kantor dan waktu memulai dan sampai penutupan rapat serta seminar dan sebagainya.

2. Disiplin moral, yaitu kedisiplinan yang berasal dari dalam hati seseorang untuk berusaha mengerjakan suatu pekerjaan. Disiplin pada moral akan muncul pada pertanggung jawaban juga selesai atau belumnya pekerjaan itu.

3. Disiplin administratif, Adalah sikap disiplin antara mau atau tidak untuk melakukan pekerjaany, misalkan yang ada pada aturan atau kaidah yang sudah disepakati sebelumnya. Aturan itu boleh bersifat tertulis dan tidak tertulis, boleh seperti suatu norma hukum, norma kesusilaan, peraturan kepegawaian dan lainnya.

Wilson Bangun (2012: 231) berpendapat Kinerja (performance) merupakan hasil pekerjaan yang dicapai seseorang didasarkan pada persyaratan pekerjaannya. Anwar Prabu Mangkunegara (2009:75) berpendapat bahwa indikatornya kinerja, adalah :

1. Kualitas, adalah hasil pekerjaannya yang dilakukan hampir sempurna, atau seberapa baik seorang pegawai dalam mengerjakan pekerjaanya.

2. Kuantitas, adalah nilai atau sasaran yang diperoleh dikemukakan dalam istilah unit atau jumlah pekerjaan yang selesaikan, Kuantitas kerja juga diartikan dari berapa lamakah seorang pegawai kerja dalam satu hari. Kuantitas kerja juga dapat dilihat melalui cepatnya kerja masing-masing setiap pegawai.

3. Pelaksanaan tugas, adalah sejauh mana seorang pegawai akan bekerja dengan sangat akurat dan tidak ada kesalahan

4. Tanggung Jawab, adalah kesadaran dari sebuah kewajiban seorang pegawai untuk bekerja sesuai dengan tugas yang diberikan instansi.

\section{Kerangka Pemikiran}

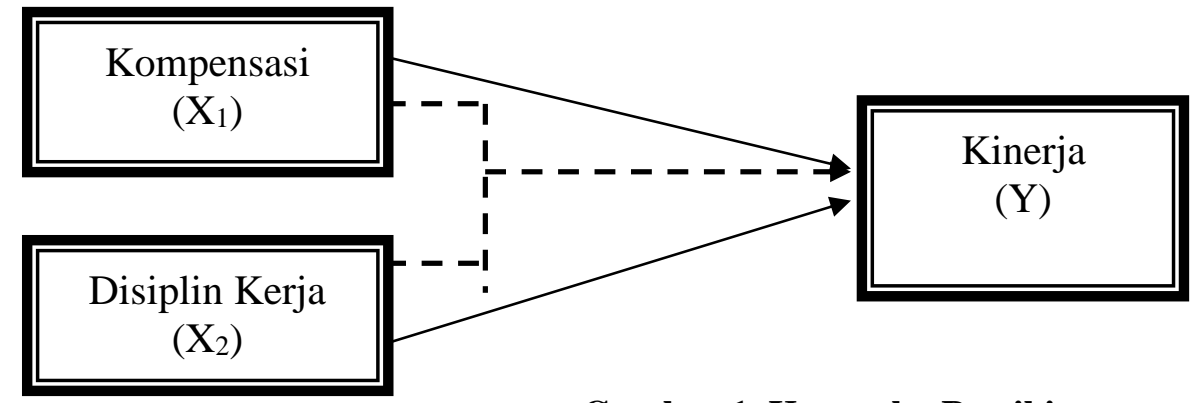

Gambar 1. Kerangka Pemikiran

Keterangan:

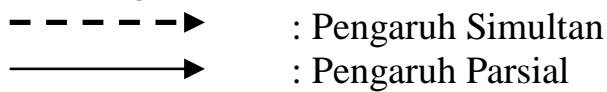

\section{Hipotesis}

1. Kompensasi dan disiplin kerja berpengaruh secara serempak pada kinerja pegawai di Dinas Bina Marga dan Penataan Ruang Prov. Sulawesi Tengah 
2. kompensasi berpengaruh secara parsial pada kinerja pegawai di Dinas Bina Marga dan Penataan Ruang Prov. Sulawesi Tengah

3. Disiplin Kerja berpengaruh secara parsial pada kinerja pegawai di Dinas Bina Marga dan Penataan Ruang Prov. Sulawesi Tengah

\section{METODE PENELITIAN}

Penelitian asosiatif adalah jenis dari penelitian ini. Dasar pemilihan jenis penelitian ini adalah karena Penelitian asosiatif merupakan penelitian yang tujuannya adalah mengetahui pengaruh atau juga hubungan diantara 2 variabel atau lebih (Sugiyono 2013:80). Peneliti ingin mengetahui pengaruh antara kompensasi dan disiplin kerja pada kinerja pegawai honorer Dinas Bina Marga dan Penataan Ruang Prov. Sulawesi Tengah.

Populasi adalah keseluruhan daerah yang terdiri atas: obyek/subyek yang punya kualitas dan kategori sendiri yang digunakan seorang peneliti untuk dipelajari lalu kemudian ditarik kesimpulan, Sugiyono (2016:80). Seluruh pegawai honorer yang bekerja di Dinas Bina Marga dan Penataan Ruang Prov.Sulawesi Tengah adalah populasi pada penelitian ini, yang berjumlah 62 orang pegawai. Penelitian dengan menggunakan metoden sensus, seluruh populasi yaitu sebanyak 62 orang pegawai honorer akan dijadikan sebagai responden. Peneliti hanya meneliti pegawai honorer sebagai subjek penelitian dikarenakan pegawai honorer ditempat penelitian dinilai masih kurang maksimal dalam bekerja sehingga dapat menurunkan kinerja instansi untuk itu perlu dilakukan perbaikan kembali sehingga akan meningkatkan kinerja pegawai tidak hanya pegawai tetap tetapi juga pegawai honorer itu sendiri.

\section{Pengujian Instrumen Penelitian}

Sebelum data dikumpulkan dan diolah, maka sebelumnya peneliti perlu melakukan uji coba instrumen terlebih dahulu, guna menegetahui tingkat validitas dan reliabilitas suatu instrument.

\section{Uji Validitas}

Suatu skala pengukuran dikatakan valid apabila adanya kesamaan diantara data yang terkumpul dengan data yang sebenarnya terjadi pada obyek penelitian. Selanjutnya valid artinya instrumen itu bisa dipakai untuk mengukur apa yang sebenarnya diukur. Sebuah instrumen dikatakan valid apabila memiliki koefisien korelasi (corrected item total correlation) $\geq 0,3$, kebalikannya bila koefisien korelasi $<0,3$ maka berarti tidak valid (Sugiyono, 2013:188).

\section{Uji Reliabilitas}

Menurut Kurniawan (2014: 195) Uji reliabilitas digunakan untuk mengetahui bisakah alat pengumpul data menunjuk tingkat tepatnya, akuratannya, stabilnya, dan konsistesial alat itu untuk pengungkapan gejala - gejala dari objek yang diteliti. Uji reliabilitas ini diuji kepada semua pernyataan yang telah valid, untuk menunjukan sampai manakah hasil pengukuran itu konsisten jika dilakukan pengukuran kembali dengan gejala yang sama. Uji statistik Cronbach's Alpha >0,60. Jika nilai Cronbach's Alpha < 0,60 hal ini menunjukan bahwa terdpat responden yang tidak menjawab konsisten.

\section{Metode Analisis}

1. Uji Normalitas

Menurut Kurniawan (2014: 156) Normalitas tujuannya menguji benarkah didalam suatu model regresi, variabel dependen dan variabel independen atau bahkan semuanya memiliki distribusi normal ataukah tidak. Model regresi yang terbaik yaitu distribusi datanya normal bahkan hampir normal. Deteksi normalitas dikerjakan dengan melihat penyebaran data (titik) di sumbu diagonal pada grafik.

2. Uji Multikolinieritas

Menurut Kurniawan (2014: 157) Uji multikolinearitas bertujuan untuk melihat adanya atau tidaknya korelasi yang tinggi diantara semua variabel bebas pada bentuk model regresi linear berganda. apabila ada 
korelasi yang tinggi diantara semua variabel bebasnya, maka hubungan diantara variabel-variabel bebas kepada variabel terikat jadi terganggu.

3. Uji Heteroskedastisitas

Uji heteroskedastisitas yaitu akan melihat adakah menunjukan ketidaksamaannya varians dari residual satu ke pengamatan yang lain. Model regresi untuk pemenuhan persyaratan yaitu dimana adanya kesamaan varians dari residual satu pengamatan ke pengamatan lainnya tetap atau disebutnya homoskedastisitas (Kurrniawan 2014: 158).

4. Regresi Linear Berganda

Analisis regresi berganda merupakan alat untuk memperkirakan atau memprediksikan hasil pengaruh dua variabel bebas $(\mathrm{X})$ atau lebih $\left(\mathrm{X}_{1}, \mathrm{X}_{2}, \ldots, \mathrm{X}_{\mathrm{n}}\right)$ pada satu variabel terikat $(\mathrm{Y})$, sehingga membuktikan ada atau tidak hubungan fungsionalnya atau hubungan kausalnya diantara dua atau lebih variabel bebas pada satu variabel terikat (Danang Sunyoto 2015:102). Analisis regresi berganda dihitung dengan menggunakan rumus sebagaai beriikut:

$$
\mathbf{Y}=\mathbf{a}+\mathbf{b}_{1} \mathbf{X}_{1}+\mathbf{b}_{2} \mathbf{X}_{2}+\mathbf{e} \ldots \ldots \ldots \ldots \ldots \ldots
$$

Keterangan:

$$
\begin{array}{ll}
\mathrm{A} & =\text { Konstanta } \\
\mathrm{Y} & =\text { Kinerja } \\
\mathrm{b}_{1}, \mathrm{~b}_{2}, \mathrm{~b}_{3} & =\text { Koefisien Regresi masing-masing Variabel } \\
\mathrm{X}_{1} & =\text { Kompensasi } \\
\mathrm{X}_{2} & =\text { Disiplin Kerja } \\
\mathrm{E} & =\text { Term Error (Tingkat Kesalahan) }
\end{array}
$$

\section{HASIL DAN PEMBAHASAN}

Berikut ini adalah hasil uji valid dan reliabel atas item pernyataan yang terdapat dalam kuesioner penelitian terhadap variabel kompeensasi (X1), diisiplin kerja (X2) dan kinerja (Y). Adapun hasilnya disajikan dalam tabell 1 beriikut:

Tabel 1 Hasil Uji Validitas dan Reliabilitas Instrumen Penelitian

\begin{tabular}{cccccc}
\hline Variabel & Item & $\begin{array}{c}\text { Total } \\
\text { Correlation }\end{array}$ & Ket & $\begin{array}{c}\text { Cronbach } \\
\text { Alpha }\end{array}$ & Ket \\
\hline & $\mathrm{X} 1.1$ & 0,527 & Valid & & \\
$\mathrm{X} 1.2$ & 0,494 & Valid & & \\
$\mathrm{X} 1.3$ & 0,678 & Valid & & \\
& $\mathrm{X} 1.4$ & 0,593 & Valid & & \\
Kompensasi & $\mathrm{X} 1.5$ & 0,663 & Valid & & \\
(X1) & $\mathrm{X} 1.7$ & 0,624 & Valid & 0.861 & \\
& $\mathrm{X} 1.8$ & 0,711 & Valid & & \\
& $\mathrm{X} 1.9$ & 0,535 & Valid & & \\
$\mathrm{X} 1.10$ & 0,485 & Valid & & \\
$\mathrm{X} 1.11$ & 0,349 & Valid & & \\
$\mathrm{X} 1.12$ & 0,491 & Valid & & \\
& & & Valid & & \\
& & & & \\
& &
\end{tabular}


Vol. 6, No. 1, Januari 2020, 032 - 041

ISSN : 2443-3578 (On Line) / ISSN : 2443-1850 (Print)

\begin{tabular}{|c|c|c|c|c|c|}
\hline Variabel & Item & $\begin{array}{c}\text { Total } \\
\text { Correlation }\end{array}$ & Ket & $\begin{array}{c}\text { Cronbach } \\
\text { Alpha }\end{array}$ & Ket \\
\hline $\begin{array}{l}\text { Disiplin Kerja } \\
\text { (X2) }\end{array}$ & $\begin{array}{l}X 2.1 \\
X 2.2 \\
X 2.3 \\
X 2.4 \\
X 2.5 \\
X 2.6 \\
X 2.7 \\
X 2.8 \\
X 2.9\end{array}$ & $\begin{array}{l}0,718 \\
0,409 \\
0,778 \\
0,580 \\
0,565 \\
0,360 \\
0,362 \\
0,681 \\
0,636\end{array}$ & $\begin{array}{l}\text { Valid } \\
\text { Valid } \\
\text { Valid } \\
\text { Valid } \\
\text { Valid } \\
\text { Valid } \\
\text { Valid } \\
\text { Valid } \\
\text { Valid }\end{array}$ & 0,845 & Reliabel \\
\hline $\begin{array}{l}\text { Kinerja } \\
(\mathrm{Y})\end{array}$ & $\begin{array}{c}\text { Y1.1 } \\
\text { Y1.2 } \\
\text { Y1.3 } \\
\text { Y1.4 } \\
\text { Y1.5 } \\
\text { Y1.6 } \\
\text { Y1.7 } \\
\text { Y1.8 } \\
\text { Y1.9 } \\
\text { Y1.10 } \\
\text { Y1.11 } \\
\text { Y1.12 }\end{array}$ & $\begin{array}{l}0,616 \\
0,576 \\
0,610 \\
0,521 \\
0,501 \\
0,625 \\
0,476 \\
0,577 \\
0,709 \\
0,691 \\
0,725 \\
0,696\end{array}$ & $\begin{array}{l}\text { Valid } \\
\text { Valid } \\
\text { Valid } \\
\text { Valid } \\
\text { Valid } \\
\text { Valid } \\
\text { Valid } \\
\text { Valid } \\
\text { Valid } \\
\text { Valid } \\
\text { Valid } \\
\text { Valid }\end{array}$ & 0,892 & Reliabel \\
\hline
\end{tabular}

Sumber: Data diolahTahun 2018

Berdasarkan hasil uji validitas dan reliabilitas diperoleh ternyata semua variabel mempunyai koefisien Cronbach Alpha (a) lebih besar dari 0,60 maka berdasarkan syarat minimum reliabilitas lebih besar dari 0,60 maka seluruh variabel yang dipakai reliabel dan boleh dipakai kedalam penelitian ini. Sedangkan uji validitas terhadap seluruh variabel juga menunjukan nilai koefisien korelasi yang lebih besar dari 0,30 maka item pernyaataan yang ada valid untuk di gunakan.

\section{Hasil Uji Analisis Regresi Linear Berganda}

Penelitian ini memakai analisis regresi linear berganda dengan tujuan agar menguji pengaruhh kompensasi dan disiplin kerja kepada kinerja. Lebih jelasnya hasil analisis regresi linear berganda bisa di lihat pada table 2 berikut:

Tabel 2 Hasil Uji Regresi Linear Berganda Coefficients $^{\text {a }}$

\begin{tabular}{|c|c|c|c|c|c|}
\hline \multirow[b]{2}{*}{ Model } & \multicolumn{2}{|c|}{$\begin{array}{c}\text { Unstandardized } \\
\text { Coefficients }\end{array}$} & \multirow{2}{*}{$\begin{array}{c}\text { Standardzed } \\
\text { Coeficients } \\
\text { Beta } \\
\end{array}$} & \multirow[b]{2}{*}{$\mathrm{t}$} & \multirow[b]{2}{*}{ Sig } \\
\hline & $\mathrm{B}$ & Std Eror & & & \\
\hline ( Constant ) & 0,646 & 0,446 & & 1,447 & 0,153 \\
\hline Kompensasi (X1) & 0,364 & 0,064 & 0,520 & 5,705 & 0,000 \\
\hline
\end{tabular}


JURNAL ILMU MANAJEMEN UNIVERSITAS TADULAKO

Vol. 6, No. 1, Januari 2020, 032 - 041

ISSN : 2443-3578 (On Line) / ISSN : 2443-1850 (Print)

\begin{tabular}{|c|c|c|c|c|c|}
\hline Disiplin Kerja (X2) & 0,441 & 0,089 & 0,454 & 4,982 & 0,000 \\
\hline $\mathrm{R}$ & $=0,716$ & & F - hitung & $=31,03$ & \\
\hline Adjustted R square & $=0,496$ & & Sig F & $=0,000$ & \\
\hline
\end{tabular}

Sumber: Data diolah Tahun 2018

Berdasarkan table 2 tersebut, dapat ditulis dalam bentuk persamaan regresi linear berganda.Untuk lebih jelasnya bentuk persamaan diatas akan dilihat sebagaii berikut :

$$
Y=0,646+0,364 X 1+0,441 X 2 \ldots \ldots \ldots \ldots \ldots .
$$

Berdasarkan penjabaran tersebut menunjukkan bahwa, variabel independen yang di analisis yaitu variabel $\left(\mathrm{X}_{1}\right.$ dan $\left.\mathrm{X}_{2}\right)$ memberikan pengaruh positif pada variabel dependen (Y), bentuk persamaan tersebut dapat dilihat berikut ini:

1. Untuk nila konstanta yaitu 0,646 artinya kinerjanya pegawai Dinas Bina Marga dan Penataan Ruang Prov. Sulawesi Tengah sebelum ada variabel independen yaitu senilai 0,646

2. Kompensasi $\left(\mathrm{X}_{1}\right)$ dengan nilai koefisien regresi 0,364 ini artinya terjadilah pengaruh yang posiitif diantara kompensasi dan kinerja pegawai. sehingga makin sesuai kompensasi pegawai Dinas Bina Marga dan Penataan Ruang Prov. Sulawesi Tengah makaakan meningkatlah kinerja pegawai.

3. Disiplin Kerja $\left(\mathrm{X}_{2}\right)$ dengannilai koefisien regresi 0,441 maka artinya ada pengaruh positif diantara disiplin kerja dan kinerja pegawai. Dengan arti makin disiplin pegawai didalam bekerja sehingga membuat peningkatan pada kinerja pegawai tersebut.

\section{Hasil Uji Hipotesis}

Tahap selanjutnya adalah menguji signifikan hubungan atau uji $\mathrm{F}$ antara variabel penelitian yaitu kompensasi $\left(\mathrm{X}_{1}\right)$ dan disiplin kerja $\left(\mathrm{X}_{2}\right)$ pada kinerja $(\mathrm{Y})$ dan perhitungannya memakai SPSS 16.0 dengan hasil dibawah ini:

Tabel3 Hasil Uji F (Simultan)

ANOVA $^{\mathrm{a}}$

\begin{tabular}{|l|r|r|r|r|r|}
\hline Model & Sum of Squares & df & Mean Square & F & Sig. \\
\hline Regresion & 3,581 & 2 & 1,791 & 31,035 &, $000^{\mathrm{b}}$ \\
1 Residual & 3,404 & 59 &, 058 & & \\
Total & 6,985 & 61 & & & \\
\hline
\end{tabular}

Berdasarkan tabel 3 di atas diperoleh Sig.F yaitu 0. 000, artinya nilai ini lebih kecil dibandingkan dengan nilai seperti disyaratkan yaitu $\alpha=0.05$ dengan tingkat kepercayaan 95\%. Sehingga hal ini dapat di nyatakan bahwa secara simultan variabel kompensasi dan disiplin kerja secara simultan signifikan berpengaruh pada kinerja pegawai.

\section{Hasil Pengujian Hipotesis Secara parsial (Uji t)}

Hasil Uji t adalah untuk mengetahui apa benar variabel $\left(\mathrm{X}_{1}-\mathrm{X}_{2}\right)$ secara parsial berpengaruh pada $\mathrm{Y}$. Untuk lebih jelasnya hasil akan terlihat di tabel4 berikut:

\section{Tabel4 Hasil Uji T(Parsial)}




\begin{tabular}{|c|c|c|c|}
\hline \multicolumn{2}{|c|}{ Model } & t & Sig \\
\hline \multirow{3}{*}{1} & $($ Constant $)$ & 1.447 & .153 \\
\cline { 2 - 4 } & $\mathrm{X}_{1}$ & 5,705 & .000 \\
\cline { 2 - 4 } & $\mathrm{X}_{2}$ & 4,982 & .000 \\
\hline
\end{tabular}

Sumber: Datadiolah Tahuun 2018

Didasarkan tabel 4 diatas hasil uji t pengujian variabel $(\mathrm{X} 1-\mathrm{X} 2)$ pada Y dijelaskan seperti dibawah ini:

\section{Hasil Pengujian Hipotesis X1 terhadap $Y$}

Hipotesis kedua $\left(\mathrm{H}_{2}\right)$ adalah agar mengetahui apaka kompensasi $\left(\mathrm{X}_{1}\right)$ secara parsial signifikan berpengaruh pada kinerja pegawai. Berdasarkan table di atas menunjukkan bahwa kompensasi $\left(\mathrm{X}_{1}\right)$ memiliki nilai signifikan senilai 0. 000. Artinya nilai itu <dari taraf yang disyaratkan yaitu $\alpha=0.05$, sehingga akan di simpulkan bahwa secara parsial kompensasi signifikan berpengaruh pada kinerja pegawai.

\section{Hasil Pengujian Hipotesis Hasil $\mathbf{X}_{2}$ terhadap $\mathbf{Y}$}

Hipotesis ketiga $\left(\mathrm{H}_{3}\right)$ adalah agar kita tahu apakh disiplin kerja $\left(\mathrm{X}_{2}\right)$ secara parsial pengaruhnya signifikan pada kinerja pegawai. Berdasarkan Table diatas menunjukan bahwa disiplin kerja $\left(\mathrm{X}_{2}\right)$ mempunyai nilai signifikan sebesar 0.000. Artinya nilai tersebut < dari taraf yang disyaratkan yaitu $\alpha=0$. 05, hingga akan di simpulkan bahwa secara parsial disiplin kerja pengaruhnya signifikan pada kinerja pegawai.

\section{Pembahasan atau Hasil Analisis Secara Simultan}

Merujuk pada hasil pengujian hipotesis pertama yaitu Uji F menunjukan ternyata ada pengaruh secara serempak variabel kompensasi dan disiplin kerja yang signifikan kepada kinerja pegawai. Dan hasil analisis regresi linier berganda menunjukan nilai signifkansi $\mathrm{F}=0,000$ lebih keciil 0, 05 dengan arti kompensasi dan disiplin kerja mempunyai pengaruh secara serempak dan signifikan kepada kinerja pegawai. Hasil itu mempunyai arti hipotesis kesatu yang menyatakan kompensasi dan disiplin kerja berpengaruh secara serempak atau bersama sama kepada kinerja pegawai, diterima. Hal itu mengindikasikan bahwa kedua variabel independen itu mempunyai pengaruh kepada peningkatan kinerja pegawai, baik dari segi kompensasi yaitu gaji, insentif, fasilitas dan tunjangannya, dan dari segi disiplin kerja yaitu disiplin waktu, moral dan administratif.

Hasil penelitian inipun sejalan dengan peneltian yang dilakukan oleh Muliati (2014:72) menyatakan ternyata variabel kompensasi dan disiplin kerja secara bersama-sama brpengaruh positif serta signifikan kepada kinerja pegawai Dinas Bina Marga Prov. Sulawesi Tengah.

\section{Pembahasan atau Hasil Analisis Secara Parsial \\ Kompensasi $\left(\mathbf{X}_{1}\right)$}

Berdasarkan hasil pengujian hipotesis kedua yaitu Uji $\mathrm{T}$ menujukan bahwa terdapat pengaruh kompensasi yang signifkan pada kinerja pegawai. Dilihat dari hasilnya analisis regresi linier berganda pada kolom koefisien regresi dengan nilai kompensasi sebesar 0,364, nilai tersebut menunjukan besarnya pengaruh kompensasi kepada kinerja pegawai di Dinas Bina Marga dan Penataan Ruang Daerah Prov. Sulawesi Tengah, yang artinya bahwa hipotess ke2 yang menyatakn bahwa kompensasi berpengaruh secara parsial dan signifikan kepada kinerjanya pegawai Dinas Bina Marga dan Penataan Ruang Prov. Sulawesi Tengah, diterima. Hasil ini memberikan makna dengan makin tingginya nilai kompensasi yang di berikan dari instansi makanya kinerjanya pegawai tersebut juga akan semakin meningkat. Kesimpulannya adalah besar kecilnya kompensasi yang diberikan pihak Dinas Bina Marga dan Pentaan Ruang Prov. Sulawesi Tengah kepada pegawainya, terutama pegawai honorer, akan mempengaruhi kinerja pegawai itu sendiri. 
Hasil pada penelitian penulis juga relevan pada penelitian yang di lakukan oleh Ayu Maristiana (2012:118) dengan hasil penelitiannya menungjukan variabel kompensasi secara parsial signifika pengaruhnya kepada kinerja pegawai PT. Rizka Tama Line di Bandar Lampung.

\section{Disiplin Kerja $\left(\mathbf{X}_{2}\right)$}

Berdasarkan kesimpulan uji hipotesis secara parsial atau uji $\mathrm{t}$ menujukan bahwa disiplin kerja signifikan mempengaruh kinerja pegawai. Dari hasil analisis regresi pada kolom koefisien regresa dengan nilai sebesar 0,441 menunjukan besarnya pengaruh disiplin kerja pada kinerja pegawai. Yang artinya bahwa hipotesis terakhir yang menyatakan bahwa disiplin kerja secara parsial signifikan berpengaruh kepada kinerja pegawai Dinas Bina Marga dan Penataan Ruang Prov. Sulawesi Tengah diterima. Nilai yang sudah dihasilkan ini menunjukkan bahwa peningkatan disiplin kerja mempengaruhi tingkat kinerja dari pegawai tersebut, oleh karena itu apabila nilai disiplin kerja meningkat tentu kinerja pegawainya pasti meningkat juga.

Hasil penelitan inipun juga sejalan dengan hasil dari penelitan yang di lakukan oleh Hardani, Bachri dan Dahniar (2016:33) dengan hasil variabel disiplin kerja berpengauh kepada kinerja pegawai negeri sipil yaitu nilainya positif dan signifikan. Hasil inipun mengungkapkan bahwa makin tinggi disiplin kerja yang dimilki oleh setiap pegawai negeri sipil pasti meningkat pula nilai kinerja pegawainya dalam hal ini adalah pegawai negeri sipil Balai Karantina Pertanian Kelas I Banjarmasi.

\section{KESIMPULAN DAN SARAN Kesimpulan}

Didasarkan pada pembahasan penelitian yang sudah dikemukakan diatas, sehingga penulis dapat menarik beberapa kesimpulan dari hasil penelitian diatas adalah sebagai berikut:

1. Kompensasi dan disiplinkerja berpengaruh secara serempak dan signifikan kepada kinerjanya pegawai honorer di Dinas Bina Marga dan Penataan Ruang Prov. Sulawesi Tengah.

2. Kompensasi pengaruhnya secara parsial dan signifkan kepada kinerja pegawai honorer pada Dinas Bina Marga dan Penataan Ruang Prov. Sulawesi Tengah.

3. Disiplin kerja berpengaruh secara parsial dan signifikan terhadap kinerja pegawai honorer di Dinas Bina Marga dan Penataan Ruang Prov. Sulawesi Tengah.

\section{Saran-Saran}

Didasarkan oleh penelitian yang sudah dikerjakan diatas dan ditarik sebuah kesimpulan, sehingga diperoleh saran-saran yang bisa digunakan oleh penelitian ini adalah sebagai berikut:

1. Dinas Bina Marga dan Penataan Ruang Prov. Sulawesi Tengah diharapkan agar lebih memperhatikan sistem kompensasi yang diberikan kepada pegawai honorer. Meningkatkan kinerja pegawai honorer, fasilitas yang diberikan harus mampu membuat pegawai merasa nyaman dan efektif dalam bekerja, misalkan dengan pemberian kendaraan dinas kepada pegawai ketika akan melakukan tugas lapangan dan tentu saja hal ini juga didasarkan pada kondisi pekerjaan tersebut.

2. Untuk terus mempertahankan dan semakin meningkatkan disiplin kerja para pegawai, pegawai sendiri harus meningkatkan kesadaran dalam dirinya akan pentingnya disiplin dalam bekerja, misalkan pegawai tidak boleh datang terlambat dan selalu masuk kantor sesuai jam yang telah ditetapkan, apabila pegawai selalu terlambat maka pihak instansi harus tegas dalam memberikan sanksi, pegawai juga harus selalu bertanggung jawab atas beban yang diberikan kepadanya, serta mampu menyelesaikan pekerjaannya sesuai prosedur yang ditetapkan. 
3. Perlu upaya untuk mempertahankan dan meningkatkan kinerja pegawai yang bekerja di Dinas Bina Marga dan Penataan Ruang Prov. Sulawesi Tengah. Kinerja Pegawai akan meningkat apabila terdapat umpan balik dari kedua pihak yaitu pegawai dan instansi, pegawai honorer harus memiliki tanggung jawab dalam bekerja dan tidak boleh bermalas-malasan. Pihak instansi juga perlu memperbanyak pelatihan-pelatihan dalam bentuk penerimaan materi maupun tugas lapangan, hal ini dilakukan untuk terus mengasah kemampuan mereka sehingga semakin lama kemampuan mereka akan semakin meningkat serta memiliki inisiatif untuk terus maju dan menghasilkan kinerja-kinerja yang baik kedepannya.

4. Disarankan agar peneliti selanjutnya yang akan meneliti atau melanjutkan penelitian ini, dianjurkan agar diteruskan dan dikembangkan penelitian ini sebagai sebuah referensi baru dengan menambah atau memperbaharui variabel dan isi dalam penelitian ini, sehingga dapat menjadi masukan yang baik bagi pegawai honorer di Dinas Bina Marga dan Penataan Ruang Prov. Sulawesi Tengah.

\section{REFERENSI}

Ayu, Maristiana. 2012. Hubungan kompensasi dengn Disiplin kerja karyawan di PT Riski Tama Line Bandar Lampung. Jurnal Organisasi dan Manajemen, Vol.2 No.2, hal. 111-119.

Bangun, Wilson. 2012. Manajemen Sumber Daya Manusia. Jakarta : Erlangga.

Hasibuan, Malayu. 2009. Manajemen Sumber Daya Manusia. Jakarta : Bumi Aksara

Hardani, Bachri dan Dahniar. 2016. Pengaruh Tunjangan Kinerja dan DisiplinKerja pada Kinerja Pegawai Negeri Sipil Balai Karantina Pertanian kelas I Banjarmasin. Jurnal Wawasan Manajemen, Vol. 4, Nomor 1, hal. 23-37.

Kurniawan, Albert 2014. Metode Riset untuk Ekonomi dan Bisnis. Bandung : Alfabeta.

Mangkunegara, Anwar Prabu. 2009. Manajemen Sumber Daya Manusia Perusahaan. Bandung: Remaja Rosdakarya

Muliati, 2014. Pengaruh Kompensasi, Disiplin Kerja dan Lingkungan Kerja terhadap Kinerja Pegawai pada Dinas Bina Marga Sulawesi Tengah. e-Jurnal Katalogis. Volume 2 Nomor 7, hal. 68-77.

Sinambela, Lijan Poltak. 2012. Kinerja Pegawai Teori Pengukuran dan Implikasi. Yogyakarta: Graha Ilmu

Soetrisno, PH. 2014. Kapita Selekta Ekonomi. Edisi Kedua.Yogyakarta:Andi offset.

Sunyoto, Danang. 2015. Penelitian Sumber Daya Manusia. Edisi Pertama. Yogyakarta: CAPS

Sugiyono. 2013. Metode Penelitian Kuantitatif Kualitatif. Bandung: Alfabeta. 2016. Metode penelitian kuantitatif, kualitatif. Bandung: Alfabeta. 